\title{
Determination of Vitamin D 3 Content in High, Low and Zero Fat Food Using High Performance Liquid Chromatography
}

\author{
AHMAD M. FARAG, Ph.D. 1 ; MAHMOUD S. RIZK, Ph.D. 2 ; HAMDY A. EL-BASSEL, Ph.D. 3 and \\ MONA H. YOUSSIF, M.Sc. 4 \\ The Departments of Organic Chemistry ${ }^{1}$, Inorganic and Analytical Chemistry2, Faculty of Science, Cairo University, \\ The Department of Nutritional Biochemistry and Metabolism, National Nutrition Institute 3 and The Department of Food Science, \\ National Nutrition Institute4, Cairo
}

\begin{abstract}
Background: Vitamin D, has a significant role in bone metabolism and helps calcium absorption in the body. There are only few vitamin D assay methods available for zero fat food.

Aims of Study: (1) To develop an accurate and sensitive LC method for the quantification of vitamin $\mathrm{D}_{3}$ in food by optimization of each step of the analytical method: Extraction, sample preparation, separation and detection. (2) To validate the developed method. (3) To apply the method to quantify the total vitamin D3 in food from several species.
\end{abstract}

Material and Methods: In this study, a rapid, simple, and economical reversed phase liquid chromatographic method was described for the determination of vitamin $\mathrm{D}_{3}$, in some high, low and zero fat samples (milk products, cereal and chewing gum samples). The isolation of fat soluble vitamins includes a saponification step and an extraction step with petroleum ether and diethyl ether. The vitamin $\mathrm{D}_{3}$ content of samples was determined by reversed phase liquid chromatography. Ultra violet-Visible (UV-VIS) detector and C18 column were used for this purpose.

Results: The linearity of standard curves of vitamin $\mathrm{D}_{3}$ were 10-200 g/mel expressed of the correlation coefficient $r 2=0.9992$ ). The detection (LOD) and quantification (LOQ) limits were 5.09 and $15.42 \mathrm{~g} / \mathrm{l}$, respectively. The accuracy was $101.37 \pm 4.37$.

Conclusion: The described reversed-phase HPLC method is favorable compared with other published HPLC-UV methods (20 and 21) because of its stability-indicating nature, short run time and wide analytical range with outstanding linearity, accuracy and precision. The proposed method allows the determination of vitamin $\mathrm{D}_{3}$ in a single chromatographic run and is suitable for the analysis of the stability of vitamin $D_{3}$ The obtained results from the assay of vitamin $\mathrm{D}_{3}$ in commercial nutrition supplements confirmed that the method is appropriate for the routine analysis of various food samples.

Key Words: Analytical measurement - Dietary supplements - Fortified foods - Infant - Vitamin D.

Correspondence to: Dr. Ahmad M. Farag, The Department of Organic Chemistry, Faculty of Science, Cairo University

\section{Introduction}

VITAMIN D is very important fat soluble vitamin in human and animal diet. It exists in two forms, Vitamin $\mathrm{D}_{2}$ and $\mathrm{D}_{3}$. Vitamin $\mathrm{D}_{3}$ (cholecalciferol) is synthesized endogenously from 7 - dehydrocholesterol after ultraviolet irradiation or is absorbed from the diet [1] . Vitamin D plays an important role in the maintenance of normal levels of calcium and phosphorus in the blood stream and is essential for the proper development and maintenance of bone [2]. Both vitamins $\mathrm{D}_{2}$ and $\mathrm{D}_{3}$ are biologically inactive. In humans, they are metabolized in the liver to calciferol (25-hydroxyvitamin $\mathrm{D}_{2}$ and 25hydroxyvitamin $\mathrm{D}_{3}$, collectively known as $25(\mathrm{OH})$ $\mathrm{D})$, Vitamin D that is not metabolized in the liver is stored in the adipose tissue and skeletal muscle, then released during vitamin $\mathrm{D}$ deprivation [3]. It has also been suggested that vitamin $\mathrm{D}_{3}$ is more efficiently absorbed by the intestine than vitamin $D_{2}$ [4] . Vitamin $D$ is soluble in lipids. Therefore the amount of fat in a meal may affect bioavailability with potentially higher vitamin $\mathrm{D}$ absorption from consumption in a higher fat food or meal [s

Vitamin D deficiency is not only related to muscle weakness and osteomalacia, but has also been associated with cardiovascular disease, cancer, autoimmune diseases, diabetes mellitus and hypertension [6]. Furthermore, newborn babies may be affected in their normal growth and development, putting them at risk of long-term physical deficits [7].

HPLC methods offer the best approach to accurate determination of vitamin $\mathrm{D}_{3}$ content in foods and pharmaceuticals, as well as stability testing. In the last decade, high-performance liquid chromatography coupled to mass spectrometry has 
become the technique of choice for vitamin $\mathrm{D} 3$ determination in foods, feeds and pharmaceuticals [8].

\section{Vitamin D chemistry:}

Vitamin D exists in a number of forms, where the major physiologically relevant forms are vitamin D2 (ergocalciferol) and vitamin D 3 (cholecalciferol) (Fig. 1) [9]. Vitamin D2 is produced by ultraviolet B (UVB) irradiation of the plant steroid ergosterol. Vitamin D 3 is synthesised in the skin of vertebrates through the action of UVB and 7dehydrocholesterol. Vitamin D 2 is the less common form of vitamin $\mathrm{D}$ and has potentially lower bioavailability than Vitamin D 3 [10]. Vitamin D from sunlight or dietary sources is biologically inactive and is hydroxylated, via a two step process to 1,25dihydroxyvitamin $\mathrm{D}$ (calcitriol), before it becomes metabolically active [9].

Vitamin D two major forms, cholecalciferol (vitamin D3) and ergocalciferol (vitamin D 2).

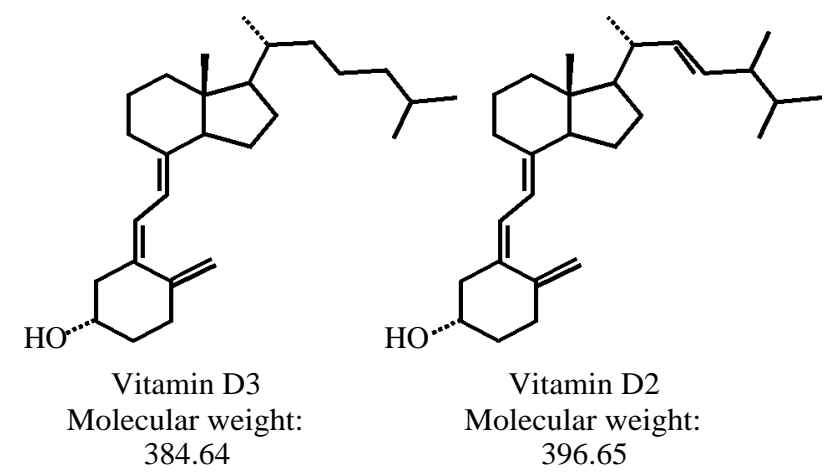

Fig. (1): Different forms of vitamin D.

\section{Material and Methods}

\section{Samples selection:}

In January 2017 In January 2017, products were purchased for this pilot study from the local supermarkets in Cairo governorate, Egypt, the selection included the majority of the available brands, and all products were brought within the best-before date. To study the potential difference in vitamin D content between labeled and measured concentration, triple of products of the same brand but each with a different best-before date were brought.

According to the South African Food Data System (SAFOODS), full cream milk contains at least $3.3 \mathrm{~g}$ of fat per $100 \mathrm{ml}$ of which $2.1 \mathrm{~g}$ is saturated fat. Low fat contains not more than $1.9 \mathrm{~g}$ of fat per $100 \mathrm{ml}$ of which $1.2 \mathrm{~g}$ is saturated. On the other hand fat-free or skim milk contains not more than $0.2 \mathrm{~g}$ of fat per $100 \mathrm{ml}$ and only a trace of saturated fat.
Vitamin D fortified foods were classified in the following two product groups:

- High fat food samples: Were included in baby milk powder and creamy cooking cheese.

- Low and Skimmed food samples: Low and zero fat food samples were selected, low fat samples included yogurt and baby food based on cereals (cerelac). While, zero fat vitamin D 3 food supplement in chewable forms were include in baby gum.

\section{Labeled vitamin D concentration:}

The labeled vitamin D concentration ( $\mu \mathrm{g} /$ $100 \mathrm{gm}$ ) was obtained by the manufacturer's label declaration for comparison with the analyzed vitamin D concentration.

It is, however, not always possible for food or supplements to contain the exact micronutrient level specified on the label, due to natural and processing variations, as well as changes during storage. But on the other hand substantial deviation from what is labeled could mislead the consumer and should be prevented [11]. The actual vitamin D concentration of fortified foods and dietary supplements may deviate from the label due to potential overages to cover losses during shelf life [12]

\section{Chemical analysis (Reagents and materials):}

All materials and reagents used in this study were pure laboratory chemicals. Potassium hydroxide pellets, sodium sulphate anhydrous, ascorbic acid were purchased from Merck. The organic solvents used include, ethanol, methanol, petroleum ether $\left(40-60^{\circ} \mathrm{C}\right)$, acetonitrileand diethyl ether peroxide free. All the used chemicals were of the highest purity available analytical grade and all solvents in this study were grade-HPLC and obtained from Merck, fluka, Fisher, sigma Aldrich Companies.

Experiments were carried out using a GBC HPLC system coupled to UV-VIS detector using single wavelength for this study, $264 \mathrm{~nm}$ for Vitamin D3. The compounds were separated with reversed phase $(250 \mathrm{~mm} \times 4.6 \mathrm{~mm}, 5 \mu \mathrm{m})$ ACE 5 C18-300 column with a $\mathrm{C} 18$ guard cartridge which maintained at room temperature. Mobile phase was (50\%: 50\%, v/v) methanol and acetonitrile HPLC grade and the flow rate was $1.00 \mathrm{~mL} / \mathrm{min}$ (isocratic elution). Total run time required was equal to 7 $\min$.

\section{Standard solutions:}

Stocks and standards solution of Cholecalciferol (vitamin D 3): Stock solution was prepared by dissolving $1 \mathrm{mg}$ of cholecalciferol standard in $1 \mathrm{ml}$ 
methanol. Serial standard solutions were prepared by using 20, 50, 100, 150 and 200 Lof stock standard solution in $10 \mathrm{ml}$ measuring flask then complete to the mark by methanol. The stock and standard solutions were stored in brown flask with screw cap to avoid exposure to light and air at $-4^{\circ} \mathrm{C}$ in refrigerator.

\section{Saponification:}

Saponification step of high fat food: Five grams of powdered or $5 \mathrm{ml}$ liquid sample weighted in $10 \mathrm{ml}$ measuring flask then complete to the mark by warm deionized water at $40^{\circ} \mathrm{C}$ and mixed for 10 min by vortex until complete homogenization occurred then $20 \mathrm{ml} 50 \% \mathrm{KOH}$ solution and 1 gram of ascorbic acid were added in $100 \mathrm{ml}$ measuring flask with covered foil and complete to the mark by ethanol with continuously shaking through over night in water bath at room temperature until the sample was completely saponified.

Saponification step of low and zero fat food: Five grams of powdered or $5 \mathrm{ml}$ liquid sample, 1 gram of rice bran oil (put in $100 \mathrm{ml}$ volumetric flask then add $20 \mathrm{ml} 50 \% \mathrm{KOH}$ solution and one gram of ascorbic acid added and completed by ethanol to mark. The solution was covered by aluminum foil with continuously shaking through over night in water bath at room temperature until the sample completely saponified) and complete as the first saponification step.

Extraction step for high and low fat and non fat food: After shaking, the sample was transferred into $500 \mathrm{ml}$ separating funnel then add $50 \mathrm{ml}$ of (50\%: $50 \%, \mathrm{v} / \mathrm{v})$ diethyl ether: Petroleum ether, shake the mixture for $20 \mathrm{~min}$. The upper and organic layer was left in the same separating funnel. The aqueous layer was re-extracted with a further $50 \mathrm{ml}$ of the mixture and the mixture was shaken for 20 $\mathrm{min}$ in another separating funnel. The two organic layers were joined and washed twice by shaking $2 \mathrm{~min}$ with $250 \mathrm{ml}$ of deionized water. The organic layer washed until no change in red $\mathrm{pH}$ paper. The organic layer was collected and evaporated by furnace at $40^{\circ} \mathrm{C}$. For reversed phase chromatography the residue dissolved in $2 \mathrm{ml}$ of methanol for determination of vitamin $\mathrm{D} 3$ was directly filtered through $0.45 \mathrm{~m}$ ilter and 20 Loxtract was injected into the HPLC system. The vitamin D 3 concentration in the samples was calculated in y/10g edible weight using peak area by comparison between standard and sample after injection.

\section{Determination of fat crud:}

$0.5-2 \mathrm{~g}$ sample was weighted in $250 \mathrm{ml}$ volumetric flask, adding $10 \mathrm{ml}$ of distilled water, $1.5 \mathrm{ml}$ ammonium hydroxide was added then the flask was immersed on water bath at $70^{\circ} \mathrm{C}$ for $15 \mathrm{~min}$ then cooled. $10 \mathrm{ml}$ of concentrated hydrochloric acid was added. The flask was heated on hot plate for $5 \mathrm{~min}$ then cooled. $25 \mathrm{ml}$ petroleum ether, $25 \mathrm{ml}$ diethyl ether and $10 \mathrm{ml}$ ethyl alcohol $95 \%$ were added and mix them and leave for 24 hour. Solvent with fat was separated in beaker (known weight). The beaker was leaved in the oven at $50^{\circ} \mathrm{C}$. The beaker was put in desiccator until cool then the beaker weighted with fat.

- Weight of fat $=$ Weight of beaker with fat - Weight of beaker

- \% Crude fat $=($ Weight of fat $/$ Weight of sample $)$ x 100

\section{Results}

Table (1) shows the measured and labeled fat content in high fat food (represented by creamy cooked cheese and baby infant milk powder), low fat food (represented by yogurt and baby food based on cereals) and zero fat food (represented by baby gum).

Table (1): Determination of crud fat and comparison with label information.

\begin{tabular}{|c|c|c|c|c|c|c|}
\hline Fat $g / 100 \mathrm{~g}$ & $\begin{array}{l}\text { Label } \\
\text { concentration g/100g }\end{array}$ & $\begin{array}{c}\text { Found } \\
\text { concentration } \mathrm{g} / 100 \mathrm{~g}\end{array}$ & Mean & SD & $\underset{\%}{\mathrm{RSD}}$ & $\underset{\%}{\text { Recovery }}$ \\
\hline 1- Fat in (creamy cooked cheese) cheese & 25 & $\begin{array}{l}24.08 \\
24.14 \\
24.75\end{array}$ & 24.32 & 0.37 & 1.52 & 97.29 \\
\hline 2- Fat in baby infant milk powder & 26.1 & $\begin{array}{l}25.81 \\
25.37 \\
25.74\end{array}$ & 25.64 & 0.24 & 0.92 & 98.24 \\
\hline 3- Fat in yogurt & 3 & $\begin{array}{l}2.83 \\
2.59 \\
2.70\end{array}$ & 2.71 & 0.12 & 4.44 & 90.22 \\
\hline 4- Fat in baby food based on cereals & 0.55 & $\begin{array}{l}0.47 \\
0.51 \\
0.46\end{array}$ & 0.48 & 0.026 & 5.51 & 87.27 \\
\hline 5- Fat in baby gum & 0 & 0 & 0 & 0 & 0 & 0 \\
\hline
\end{tabular}


The number of vitamin D fortified foods has increased. The food type with the greatest increase was yoghurt, Fortified skim milks and reduced fat milks [13]. Fortification can be achieved in multiple ways with varying efficiency. For example, vitamin D3 was added by: Addition of water-soluble emulsion, or crystalline liposoluble vitamin D [14] Vitamin D 3 was fortified into yoghurt in either a crystalline or emulsified form; both forms of vitamin D3 were stable in yoghurt during storage for the expected shelf lives of the products [15]. In an evaluation of increasing the level of vitamin D 3 fortification in high temperature processed reduced fat milks and low-fat yoghurt serving, no loss of vitamin D3 during processing was found [16]. Vitamin $\mathrm{D} 3$ has also been shown to be stable in a non-fat food, with no change [17]. Study by [18] strongly recommend food industries to use opaque containers for storage of yogurt products or even any kinds of foodstuffs fortified with Vitamin D 3 to reduce light-related degradation of the vitamin during the products shelf-life.

\section{Calibration curve of vitamin D3:}

The linearity of standard curves (Table 2) was expressed in terms of the determination coefficient $\left(r^{2}\right)$ from plots of the integrated peak area versus concentration of the standard ( $/ / m$ ) These equations were obtained over a wide concentration range, in accordance with the levels of these compounds found in food samples. Linear equations were found, with satisfactory linearity $\left(r^{2}>0.99\right)$.

Table (2): Vitamin D3 Calibration curve analysis.

\begin{tabular}{llcc}
\hline $\begin{array}{l}\text { Concentration } \\
\text { g/nl }\end{array}$ & $\begin{array}{c}\text { Beak } \\
\text { area }\end{array}$ & $\begin{array}{c}\text { Found concentration } \\
\text { g/nd }\end{array}$ & Recovery\% \\
\hline 20 & 111 & 20.84827 & 104.2413 \\
50 & 286 & 49.51563 & 99.03126 \\
100 & 579 & 97.51298 & 97.51298 \\
150 & 920 & 153.3734 & 102.2489 \\
200 & 1197 & 198.7497 & 99.37486 \\
\hline
\end{tabular}

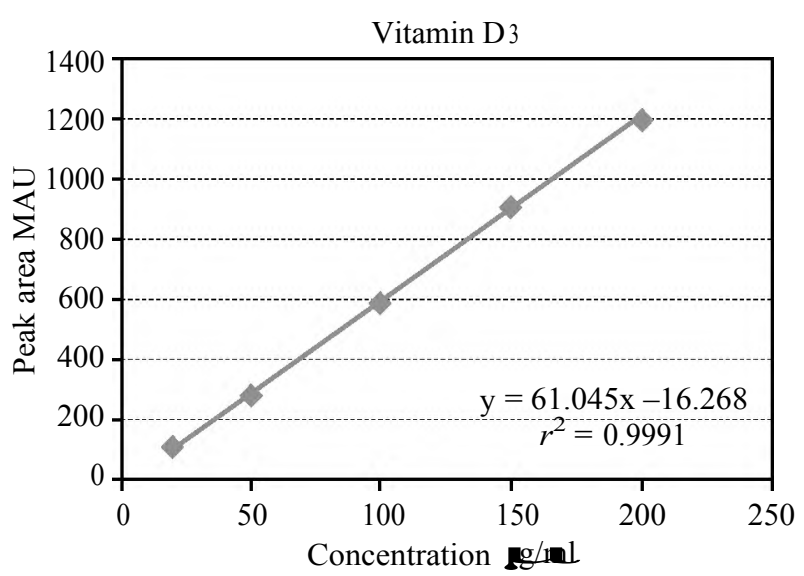

Fig. (2): Calibration curve of vitamin D 3

\section{Validation of vitamin D3:}

Validation studies were performed by measuring basic parameters such as precision, accuracy, linear region, limits of detection (LOD) and quantification (LOQ), and recovery.

Table (3): Validation sheet of vitamin D.

\begin{tabular}{ll}
\hline Parameter & Values \\
\hline Accuracy & $100.48 \pm 2.71$ \\
Slope & 6.10 \\
Intercept & -16.27 \\
Linear Range & $20-200(\mathbf{g} / \mathbf{m})$ \\
Correlation Coefficient $(r)$ & 0.9991 \\
Standard Error & 13.28 \\
Variance & 6.10 \\
LOD & 6.53 \\
LOQ & 21.76 \\
\hline
\end{tabular}

Quality control chart of vitamin D3:

10 samples of standard reference material ${ }^{\circledR}$ 1849 a prepared by this method.

- Mean $=1.11 \mathrm{~g} / 100 \mathrm{~g}, \mathrm{SD}=0.085$

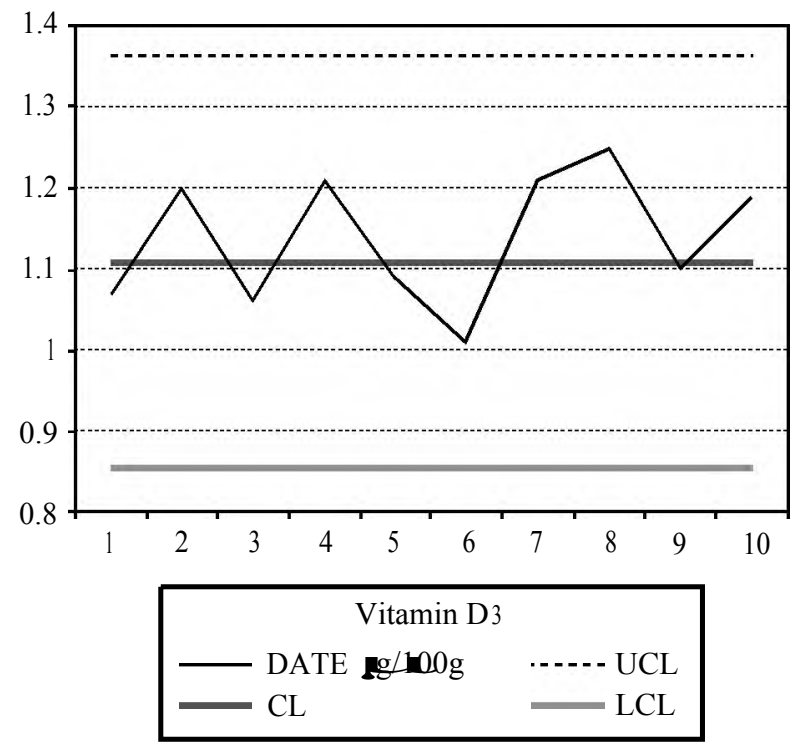

Fig. (3): Quality control chart of vitamin D 3.

Vitamin D3 in Creamy cooked cheese:

Fig. (4) shows measured vitamin D 3 concentration ( $100 \mathrm{~g}$ ) in creamy cooked cheese compared to the vitamin D content declared on the label, the measured vitamin $\mathrm{D} 3$ content ranged between $87.5 \%$ and $96.4 \%$ of the declared value. 


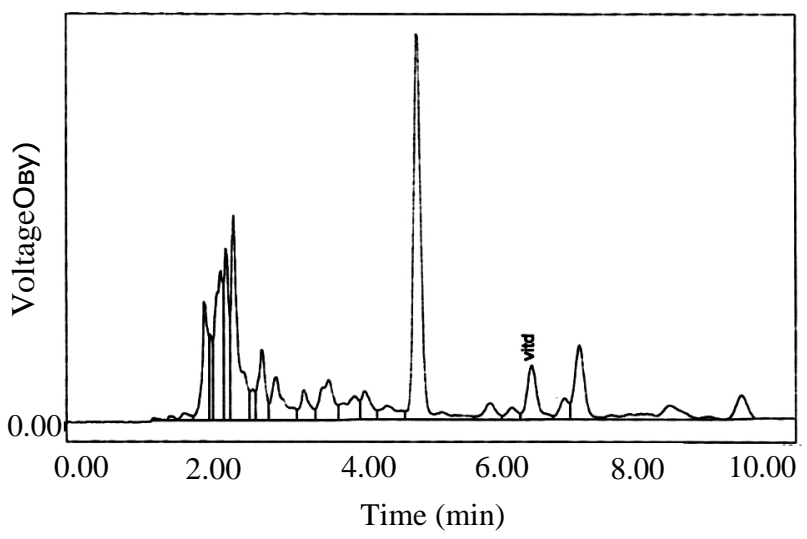

Fig. (4): Vitamin $D_{\underline{3}}$ in creamy cooked cheese.

Vitamin $D_{3}$ in Baby infant milk powder:

Fig. (5) shows measured vitamin D3 concentration ( $g \mathrm{~g}$ per $100 \mathrm{~g}$ ) in baby infant milk powder compared to the vitamin D content declared on the label, the measured vitamin $\mathrm{D}_{3}$ content ranged between $91.5 \%$ and $96.2 \%$ of the declared value.

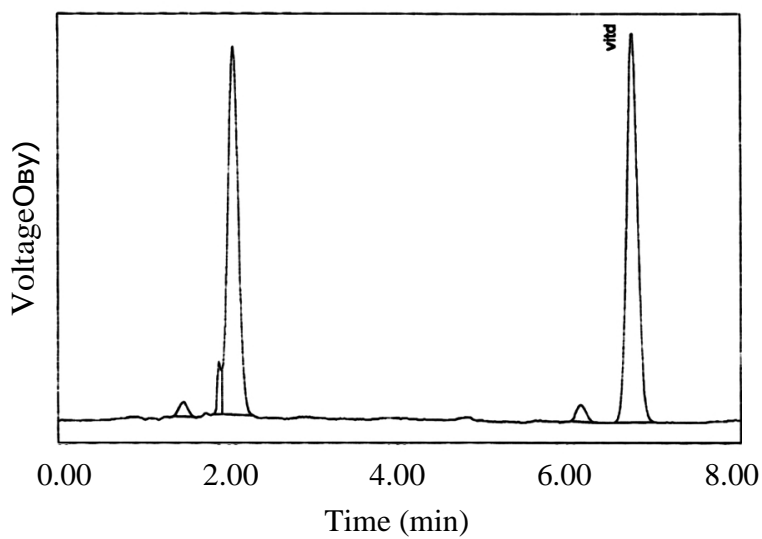

Fig. (5): Vitamin $\mathrm{D}_{\underline{3}}$ baby in infant milk powder.

Vitamin $D_{3}$ in Yogurt:

Fig. (6) shows measured vitamin $\mathrm{D}_{3}$ concentration (gg per $100 \mathrm{~g}$ ) in yogurt compared to the vitamin D content declared on the label, the measured vitamin $\mathrm{D}_{3}$ content ranged between $82.3 \%$ and $89 \%$ of the declared value.

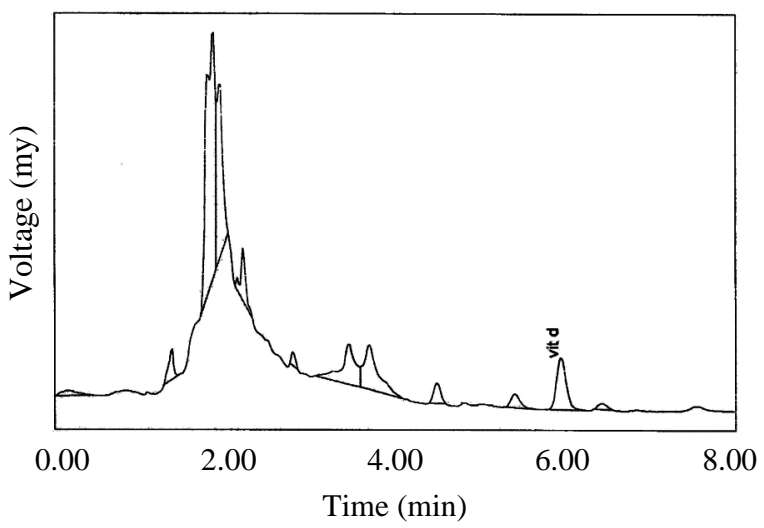

Fig. (6): Vitamin $\mathrm{D}_{\underline{3}}$ in yogurt.
Vitamin $D_{3}$ in Baby food based on cereals:

Fig. (7) shows measured vitamin $\mathrm{D}_{3}$ concentration ( $g \mathrm{~g}$ per $100 \mathrm{~g}$ ) in yogurt compared to the vitamin $\mathrm{D}$ content declared on the label, the measured vitamin $\mathrm{D}_{3}$ content ranged between $91.4 \%$ and $96.4 \%$ of the declared value.

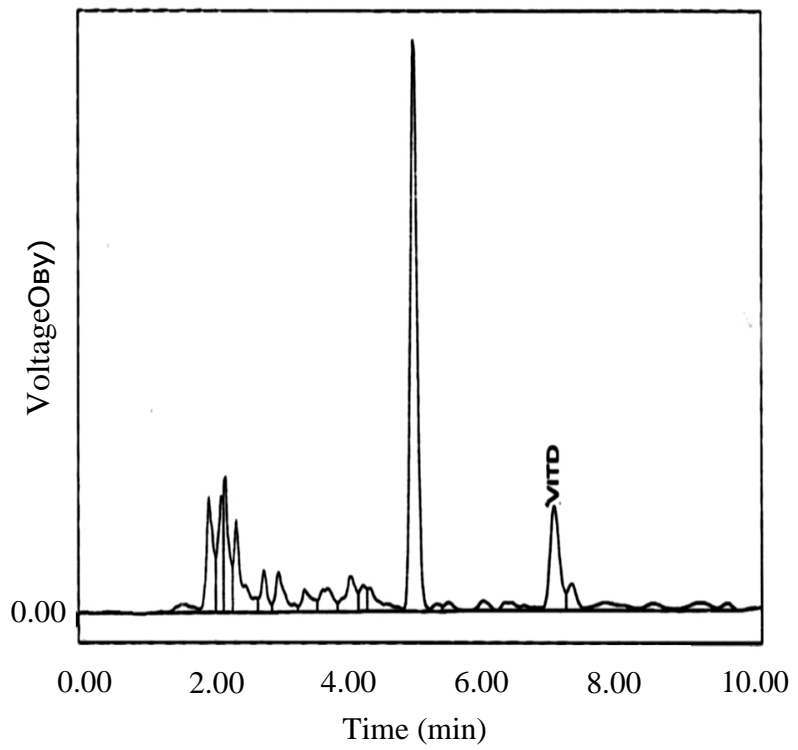

Fig. (7): Vitamin $\mathrm{D}_{3}$ in baby food based on cereals.

\section{Vitamin $D_{3}$ in Baby gum:}

Fig. (8) shows measured vitamin $\mathrm{D}_{3}$ concentration ( $\mathrm{gg}$ per $100 \mathrm{~g}$ ) in herba land kids gummy compared to the vitamin $\mathrm{D}$ content declared on the label, the measured vitamin $\mathrm{D}_{3}$ content ranged between $93.5 \%$ and $96.5 \%$ of the declared value.

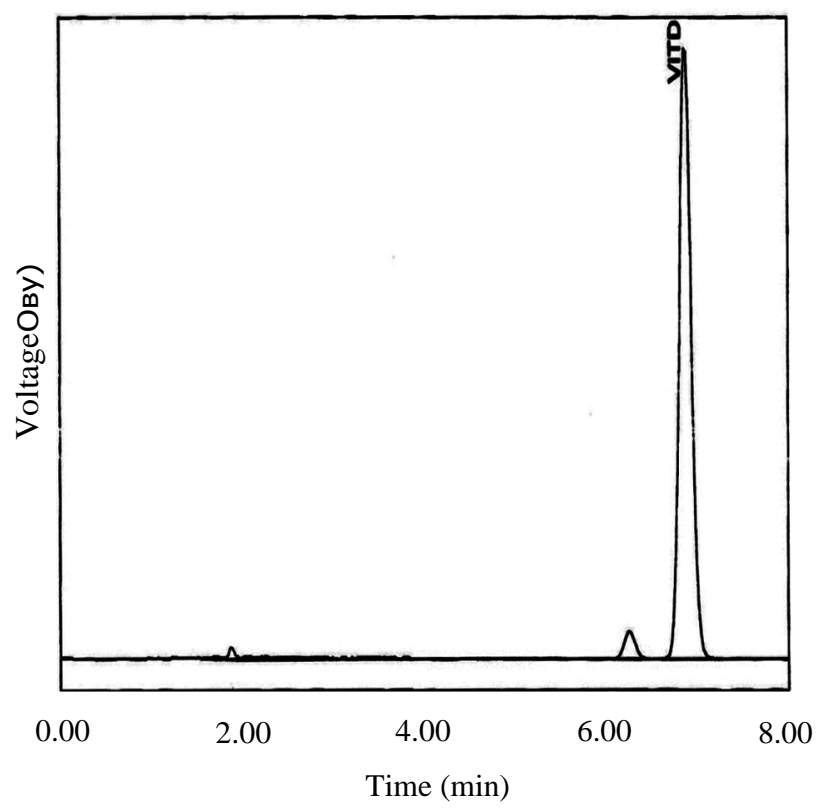

Fig. (8): Vitamin $D_{3}$ in baby gum. 
Table (4): Overview of labeled and measured vitamin D 3 contents in fortified foods and dietary supplements.

\begin{tabular}{|c|c|c|c|c|c|c|}
\hline Vitamin D3 Her $100 \mathrm{~g}$ & $\begin{array}{l}\text { Label } \\
\text { concentration } \\
\mathrm{g} / 100 \mathrm{~g}\end{array}$ & $\begin{array}{l}\text { Found } \\
\text { concentration } \\
\mathrm{g} / \mathrm{H} 0 \mathrm{~g}\end{array}$ & Mean & SD & $\begin{array}{c}\mathrm{RSD} \\
\%\end{array}$ & $\begin{array}{c}\text { Recovery } \\
\%\end{array}$ \\
\hline 1- Vitamin D3 in creamy cooked cheese & 2.5 & $\begin{array}{l}2.18 \\
2.32 \\
2.41\end{array}$ & 2.32 & 0.116 & 5 & 92.8 \\
\hline 2- Vitamin D3 in baby infant milk powder & 10 & $\begin{array}{l}9.62 \\
9.58 \\
9.15\end{array}$ & 9.45 & 0.26 & 2.76 & 94.5 \\
\hline 3- Vitamin D3 in yogurt & 3 & $\begin{array}{l}2.67 \\
2.47 \\
2.52\end{array}$ & 2.55 & 0.104 & 4.08 & 93.33 \\
\hline 4- Vitamin D3 in baby food based on cereals & 5 & $\begin{array}{l}4.61 \\
4.57 \\
4.82\end{array}$ & 4.67 & 0.134 & 2.88 & 90.59 \\
\hline 5- Vitamin D3 in baby gum & 170 & $\begin{array}{l}165 \\
159 \\
164\end{array}$ & 154 & 3.53 & 2.96 & \\
\hline
\end{tabular}

\section{Discussion}

The measured vitamin D concentrations were compared with the labeled values. The products for which the measured vitamin $\mathrm{D}$ value deviated significantly from the declared value were reanalysed

Figs. (4-8) and Table (4) show the concentrations of vitamin D 3 in food samples (creamy cooked cheese, baby infant milk powder, yogurt, baby food based on cereals and baby gum, it was found to be $2.32 \pm 0.12,9.45 \pm 0.26,2.55 \pm 0.10,4.67 \pm 0.13$ and $154 \pm 3.53 \mathrm{~g} / 10 \mathrm{~g}$ respectively and label vitamins content were $2.5,10,3,5$ and 170 . The recoveries rang $90.6 \%-94.5 \%$. The relative standard deviations were $2.8-5 \%$.

In this study, some parameters were changed in order to recommend a specific method for determination of Vitamin D 3 in high, low and zero fat content food in the both extraction and quantification stages.

In the saponification step, previous studies mainly have focused on the effect of varied temperature and time with the most confirming 70$85^{\circ} \mathrm{C}$ and 25 to $30 \mathrm{~min}$ conditions [19]

However, some studies stated that using high temperature water bath can negatively affect the saponification process $[\mathbf{2 0 , 2 1 ]}$. In this study, warm deionized water at $40^{\circ} \mathrm{C}$ and mixed for $10 \mathrm{~min}$. was applied.

In the extraction step, Formation of intractable emulation layer in this step was considered as a common problem in this step, the substitution of hexane with a more polar solvent such as ethyl ether and petroleum ether, detained emulsion formation using the wide range of food matrices.

During the washing step, ethanol addition to the distilled water used for washing solvents, which had a significant impact on separation which confirmed the results of [20] who mentioned the positive impact of ethanol in stabilizing the solution state of solvents. In the post extraction treatment, the results of this study in terms of using micro-column, confirmed the results [23] stated that solid phase extraction helped distinguishing two types of vita$\min \mathrm{D} 2$ and $\mathrm{D} 3$.

As another changing variable in this study, changing the ratio, type and amount of solvent that was used in SPE had significant effects on the performance of this treatment.

Recent studies in the field recommend microextraction as a comparable method to the classic assay which was used in the present study.

In HPLC determination of vitamin D 3, it was shown in this study that substitution of the mobile phase was (50\%: 50\%, v/v) methanol and acetonitrile instead of the pure methanol, led to better separation of vitamin D 2 and D 3 peaks, though, the vitamin $\mathrm{D} 3$ retention time became longer.

Structural similarity between vitamin D 2 and D 3 could interfere with the vitamin D 3 calculation as D2 can appear in the chromatogram with the same retention time as vitamin D3, when the applied protocol does not allow todifferentiate the two components from together. Investigating the vitamin D groups in foods, [22] reported that vitamin D2 may appear along with vitamin D 3 peak leading to false positive results. The observed peak in Figs. 
(4-8) 7 min correspond to vitamin D 3 which is higher than vitamin D2 at $6 \mathrm{~min}$. This confirms the results of Mattila in that using SPE column a clear differentiation was observed with about 2 minutes time difference in vitamin $\mathrm{D}_{2}$ and vitamin $\mathrm{D}_{3}$ retention time. This confirms the results of Mattila in that using SPE column a clear differentiation was observed with about 2 minutes time difference in vitamin $\mathrm{D} 2$ and vitamin $\mathrm{D} 3$ retention time.

Comparing the claimed and experimentally obtained values of vitamin D 3 , less than $18 \%$ difference was observed for all samples. These results are satisfactory considering the vitamin $\mathrm{D}$ content tends to decrease with time and changes in storage conditions.

\section{Recommendations:}

Based on the obtained result, application of some changes in the general vitamin D 3 measurement method can result in a more efficient assay with adequate accuracy for vitamin D 3 in fortified food.

\section{References}

1- SUBODH K., DIWESH C. and ASHOK K.: An Improved and Sensitive Method for Vitamin D 3 Estimation by RPHPLC. Pharm. Anal. Acta., 6: 8, 2015.

2- WEAVER, C. and FLEET J.: Vitamin D requirements: current and future. Am. J. Clin. Nutr., 80: 1735S-9S, 2004.

3- Institute of Medicine, Food and Nutrition Board: Dietary Reference Intakes for Calcium and Vitamin D. Washington, DC: National Academy Press, 2010.

4- LAMBERG-ALLARDT C.: Vitamin D in foods and as supplements. Prog. Biophys. Mol. Biol., 92 (1): 33-38, 2006.

5- TRIPKOVIC L., LAMBERT H., HART K., SMITH C. and BUCCA G.: Comparison of vitamin D2 and vitamin D3 supplementation in raising serum 25-hydroxyvitamin D status: A systematic review and meta-analysis. Am. J. Clin. Nutr., 95 (6): 1357-1364, 2012.

6- ROSS A., TAYLOR C., YAKTINE A. and DEL VALLE H.: Dietary reference intakes for calcium and vitamin D. Washington (DC): Institute of Medicine Committee to Review Dietary Reference Intakes for Vitamin D, Calcium, p6, 2011.

7- PRINCIPI N., BIANCHINI S., BAGGI E. and ESPOSITO S.: Implications of maternal vitamin D deficiency for the fetus, the neonate and the young infant. Eur. J. Nutr., 52 (3): 859-67, 2013.

8- SCHADT H., GOSSL R., SEIBEL N. and AEBISCHER C.: Quantification of vitamin D3 in feed, food, and pharmaceuticals using high-performance liquid chromatography/tandem mass spectrometry; Journal of AOAC International, 95 (5): 1487-1494, 2012.

9- TRUSWELL A.: Essentials of human nutrition. Oxford: Oxford University Press, 1998.
10- BORRADALE D. and KIMLIN M.: Vitamin D in health and disease: an insight into traditional functions and new roles for the 'sunshine vitamin'. Nutrition Research Reviews, 22: 118-136, 2009.

11- GARG S., SABRI D. KANJI J., RAKKAR P., LEE Y. and NAIDOO N.: Evaluation of vitamin D medicines and dietary supplements and the physicochemical analysis of selected formulations. The Journal of Nutrition, Health and Aging, 17 (2): 158-161, 2013.

12- VERKAIK J., SEVES S. and OCKÉ M.: Vitamin D concentrations in fortified foods and dietary supplements intended for infants: Implications for vitamin D intake.Food Chemistry, 221 (15): 629-635, 2017.

13- ENGELSEN O.: The relationship between ultraviolet radiation exposure and vitamin D status. Nutrients, 2(5): 482-495, 2010.

14- BANVILLE C., VUILLEMARD C. and LACROIX C.: Comparison of different methods for fortifying Cheddar cheese with vitamin D. International Dairy Journal, 10 (5-6): 375-382, 2000.

15- KAZMI S., VIETH R. and ROUSSEAU D.: Vitamin D3 fortification and quantification in processed dairy products. International Dairy Journal, 17 (7): 753-759, 2007.

16- HANSON A. and METZGER L.: Evaluation of increased vitamin $\mathrm{D}$ fortification in high-temperature, short-timeprocessed $2 \%$ milk, UHT-processed $2 \%$ fat chocolate milk, and low-fat strawberry yogurt. Journal of Dairy Science, 93 (2): 801-807, 2010.

17- BIANCUZZO R., YOUNG A., BIBULD D. and AMERI A.: Fortification of orange juice with vitamin $\mathrm{D} 2$ or vitamin D3 is as effective as an oral supplement in maintaining vitamin D status in adults. American Journal of Clinical Nutrition, 91 (6): 1621-1626, 2010.

18- TINA J., SHAGHAYEGH H., ELHAM F. and AZIZ A.: Stability of Vitamin D 3 in fortified yoghurt and yoghurt drink (Doogh). Adv. Biomed Res., 5: 52, 2016.

19- JAKOBSEN J., CLAUSEN I., LETH T. and OVESEN L.: A new method for the determination of vitamin D 3 and 25-hydroxyvitamin D3 in meat. J. Food Compos. Anal., 17 (6): 777-787, 2004.

20- MATTILA P., PIIRONEN V., BÄCKMAN C., ASUNMAA A., UUSIRAUVA E. and KOIVISTOINEN P.: Determination of vitamin D3 in egg yolk by high-performance liquid chromatography with diode array detection. J. Food Compos. Anal., 5 (4): 281-90, 1982.

21- THOMPSON J., HATINA G., MAXWELL W. and DUVAL S.: High performance liquid chromatographic determination of vitamin $\mathrm{D}$ in fortified milks, margarine, and infant formulas. J. AOAC Int., 65 (3): 624-31. 14, 1982.

22- KATHERINE M., WAYNE R. and JAMES M.: Liquid chromatography with ultraviolet and dual parallel mass spectrometric detection for analysis of vitamin D in retail fortified orange juice. Journal of Food Composition and Analysis, 24: 299-306, 2011.

23- QIAN H. and SHENG M.: Simultaneous determination of fatsoluble vitamins $\mathrm{A}, \mathrm{D}$ and $\mathrm{E}$ and pro-vitamin $\mathrm{D} 2$ in animal feeds by one-step extraction and high performance liquid chromatography analysis. J. Chromatogr., 825 (2): 127-33, 1998 


\section{تحديد محتوى فيتامين دم فى الأطعمة الغنية ، المنخفضية والخالية من الدهون الاهون بإستخدام كروماتوجرافيا السوائل عالية من الأداء}

أجريت هذه الدراسة لأستحداث طريقة أكثر دقة وسهولة من الطرق السابقة لتقدير فيتامين دب بإستخدام كروماتوجرافيا السوائل عالية الأداء فى الآغذية المدعمة بفيتامين دبر.

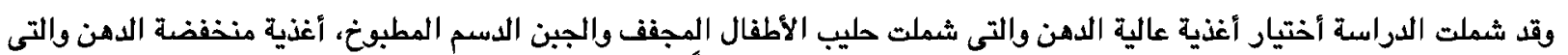

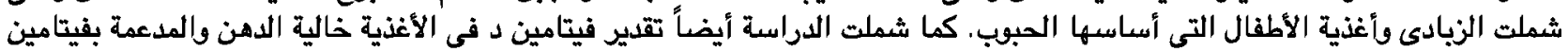

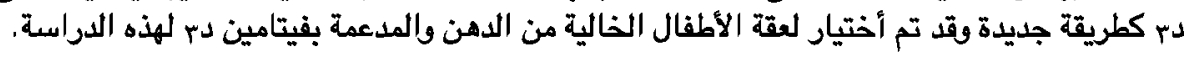
فى هذه الدراسة تم تعديل فى بعض مراحل التحديد الكمى لفيتامين D3 فى الأغذية عالية ومنخفضة الدهن كالتالى :

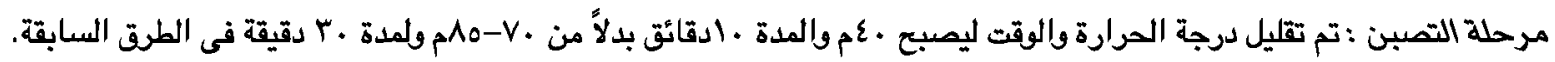
مرحلة الأستخلاص :تم استبدال الهاكسين بمذيب أكثر قطبية وهو الأثير البترولى أو الأثير الأيثيلى.

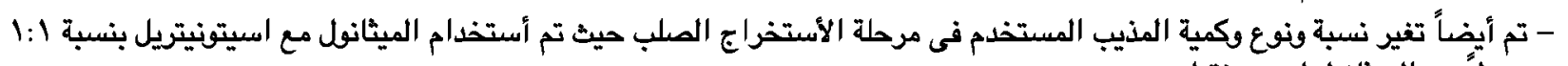

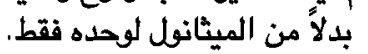
- في مرحلة الغسيل : تم إضافة الإيثانول إلى الماء المقطر المستخدم فى فسل المذييات.

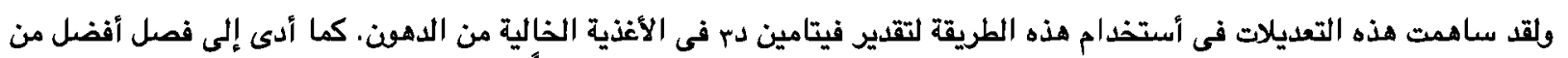

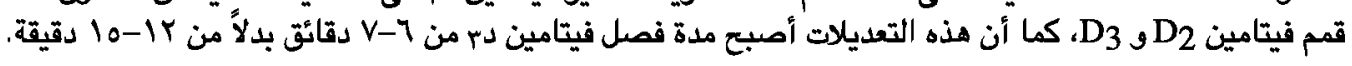

على ضوء هذه النتائج فإن هذه الطريقة مناسبة للتحليل الرتينى اللعينات الفذائية المختلفة لتحديد فيتامين D3. 